\title{
Current Status of Forest Management Unit Effectiveness Versus Decreasing The population of Sumatran Tigers in the Ulu Masen Protected Area, Aceh
}

\author{
${ }^{1}$ The University of Syiah Kuala. Doctoral Program-Agricultural Science. Aceh. Indonesia. \\ ${ }^{2}$ The University of Syiah Kuala. Agriculture Faculty. Aceh Province. Indonesia \\ ${ }^{3}$ The University of Gajah Mada. Forestry Faculty University, Yogyakarta. Indonesia \\ ${ }^{4}$ Fauna \& Flora International - Indonesia Program \\ *Corresponding author. Email: silfi.iriyani@gmail.com
}

Silfi Iriyani ${ }^{1,2^{*}}$ A. Humam Hamid ${ }^{2}$ Agus Setyarso $^{3}$ Hairul Basri $^{2}$ Dedi Kiswayadi ${ }^{4}$

\begin{abstract}
Ulu Masen ecosystem (738,000 ha) of the Aceh Province is one of the last vast wildernesses in South East Asia. IUCN categorized areas under Category VI as protected areas, primarily due to their unique cultural values and traditional natural resources management practices. It is home to the Critically Endangered Sumatran Tiger under immense pressure from habitat loss and illegal hunting. In 2013, the Governor of Aceh established forest management units (FMU) to improve the ecosystem's management. Between 2012 and 2013, a collaborative camera-trapping survey detected nine tiger individuals. In 2017, however, a repeat camera-trapping survey in approximately the same area detected only three tiger individuals. Evidence of high hunting pressure was also found during the survey to discover many active snares. A Management Effectiveness Tracking Tool assessment, which was valid through the same period of the surveys, scored the FMU performance 55 to $60 \%$. The lack of capacity in forest patrols and wildlife monitoring contributed to that low, less effective scores. We urge the Aceh government to take necessary actions to strengthen the capacity of the FMU in forest patrols and wildlife monitoring to anticipate and tackle various illegal activities.
\end{abstract}

Keywords: Ulu Masen Ecosystem, Forest Management Unit, Sumatran Tiger

\section{INTRODUCTION}

\subsection{Relevant context}

The Ulu Masen Ecosystem is covering around 738,000 ha. This area is one of two main ecosystems with high biodiversity in Aceh besides the Leuser ecosystem. These high biodiversity sites are also the umbrella species' habitat, the endangered species known as the Sumatran tiger. This site is situated on the northwestern mountain ranges stretching from close to the northern tip of Aceh to around Meulaboh city in the south [1]. Based on the IUCN category, Ulu Masen fits under Category VI as protected areas with sustainable use of natural resources, conserve ecosystems and habitats, and associated cultural values and traditional natural resource management systems [2]. The global protected area estate is the world's most considerable ever planned land use. Protected areas are not monolithic and vary in their purpose, designation, management, and outcomes [3]. The protected area's known characteristic will also define the typology of system and management practices that may deliver nature conservation objectives [3]. Based on this point of view, Ulu Masen can be managed based on its characteristic as an integrated management area.

In 2009, The Ulu Masen was proposed as a strategic protected area in Aceh based on two main functions: environmental and economic importance [4]. The area covers upland parts of Aceh Besar, Aceh Jaya, Aceh Barat, Pidie, Pidie Jaya districts, and borders on Bireun. It comprises several unique forest types, ranging from lowland karst to montane forest. The 738,000 ha of Ulu Masen landscape is rich in biodiversity, supporting over 
300 bird species and the globally significant Sumatran tiger and Asian elephant populations. It also provides invaluable social, environmental, and economic services (such as clean water supplies and flood prevention) to over a million people. Considering the Ulu Masen forest's value, it needs more innovative management to achieve the social, environmental, and economic value for sustainability in human life and biodiversity, including ecology [4].

Ulu Masen is one of the most significant homes for endangered species such as the Sumatran tiger. This area and Leuser are stated in the international document named Global Tiger Recovery in the Tiger Conservation Landscapes and Historical Range of Tigers. This documents internationally covers 13 countries, that is the People's Republic of Bangladesh, Kingdom of Bhutan, Kingdom of Cambodia, People's Republic of China, Republic of India, Republic of Indonesia, Lao People's Democratic Republic, Malaysia, Union of Myanmar, Nepal, Russian Federation, Kingdom of Thailand, Socialist Republic of Vietnam [5]. These countries agreed to develop a recovery plan for tigers. Indonesia also participated and decided to join the National Recovery Plan target of doubling the number of Sumatran tigers by 2022. Indonesia has to work hard to achieve the recovery target for doubling Sumatran tigers [6]. At this time, forest areas in Indonesia are managed by Forest Management as the smallest institution on the forest ground [7].

\subsection{What is Target Global Tiger Recovery Program}

Based on the declaration on Global Tiger Recovery Program, the 13 countries, including Indonesia, declared that they would strive to double the number of wild tigers across their range by 2022 through effectively managing and mainstreaming biodiversity conservation in the planning and development of Sumatran tiger's habitat. The second action includes improving protection habitat through forest monitoring and patrol, managing a collaborative work to eradicate poaching, smuggling, and illegal trade of tiger by strengthening national legislation, institutions, and law enforcement. Collaborative actions with the indigenous and local community are organized to minimizes negative impacts on tigers, reduce the incidents of human-tiger conflict through financial support, technical guidance, and other relevant measures based on traditional ways.

On the other hand, the effectiveness of tiger habitat management is needed to be improved through a modern and innovative application of science, standards, and technologies and by strengthening human resources and institutional capacity. In applying effective management, the effort to protect and manage tiger habitat needs more financing. One of the approaches to get financial support is by exploring and mobilizing domestic funding through forest financing mechanisms such as forest carbon fund including REDD+, payment for ecosystem services, ecotourism, private sector, other donors from NGO and partner organizations. In addition, the tiger recovery program also needs awareness-raising and participative commitment related to finances in all levels of activities.

According to the eleven statements in the Global Tiger Recovery declaration, the declaration is equipped with information about Tiger Conservation Landscapes (TCLs) referring to A User Guide of Setting Priorities for the Conservation and Recovery of Wild Tigers. The TCL ecosystem is described as the ecosystem with a high value of a viable wild tiger population. Thus, in Indonesia, Sumatra is the island that consists of TCL ecosystems. The ecosystems categorized as TCLs are supporting wild tigers and their prey and a vast amount of biodiversity. It also contributes to human wellbeing, both locally and globally. The TCL ecosystems provide cultural services, carbon storage and sequestration, poverty alleviation, watershed protection, natural hazard regulation, food security and agriculture services, medical services, and tourism [5]. The wild tiger's suitable habitat is about 1.2 million $\mathrm{km}^{2}$, covered in 13 countries in Asia, including Leuser and Ulu Masen. The most threats encountered today are habitat degradation, fragmentation, and forest loss as wild tiger ecosystems [6]. The role of the forest management unit is needed to ensure the sustainability of the wild tiger habitat. Thus, the forest management skill is now more important to be increased to achieve the National Tiger Recovery Plan (NTRP) goal that doubles the number of wild tigers, i.e., Sumatran tigers.

\subsection{The Role of Forest Management Units}

Aceh is a province under special autonomy since 2006 and is having its regulation named Qanun. Aceh forestry is regulated under Qanun Number 7/2016. Regarding conservation, Aceh also has provincial laws. The conservation for natural resources, including conservation for biodiversity, is controlled by Qanun Number 20/2002. By those regulations, there is an excellent chance to strengthen the role of FMUs, particularly regarding tiger conservation in Aceh.

FMUs strengthening is needed not only in the institutional aspect but also in human resources in the FMUs. Aceh province in forest management has not only the regulation but also forest rangers in place. About 1800 forest rangers are currently working to protect the forest from any threats. Some of the problems encountered now are illegal logging, illegal hunter, land clearing, and wildlife trafficking. This paper aims to understand the current status of FMUs' management effectiveness regarding their role as a conservation practitioners. Based on the management effectiveness, related to the prediction of decreasing 
population of Sumatran tiger in Ulu Masen area, what area of the relevant supporting to the FMUs to manage Ulu Masen global as Global Priority I of Sumatran tiger habitat as stated and declared in the Global Tiger Recovery Program.

In a local context, the FMUs were established by Governor's Regulation Number 20 the Year 2013, then amended by Governors Regulation Number 48 the Year 2018. The governor regulation stated that the responsibilities of FMUs in Aceh regarding forest management are including conservation. Besides that, Aceh also has its rule as an autonomy province by Law Number 11 the Year 2006, which accommodated the conservation issue under article number 149. Then, there is also Provincial Regulation issued by Aceh's People Council in 2002, named Qanun. The Qanun is local regulation in Aceh. The conservation Qanun for Natural Resources Conservation is Qanun Number 20 the Year 2002. In 2016, the new Qanun regarding Forestry of Aceh was issued by Aceh's People Representative Council known as Qanun Number 7 the Year 2016. In terms of policy aspect, conservation in Aceh is already comprehensive. According to the policies regarding forestry and conservation in Aceh, the FMUs as the institution on the ground level must be ensured to operate as mandated by the regulations. The strengthening of FMUs becomes a fundamental need to reach the goal of the regulations vision.

\subsection{Statement of Problem}

FMUs established to manage the forest through; effective management, including the mainstreaming of biodiversity conservation, improving protection using systematic patrolling to safeguard tigers, their prey, and habitats, working collaboratively to eradicate poaching, smuggling, and illegal trade of tigers, their parts, and derivatives, as well as increasing the effectiveness of tiger and habitat management.

\subsection{Objectives}

This study aims to identify the central area of management effectiveness status regarding forest management implemented by FMUs and identify the Sumatran tiger population's status before and after the establishment of FMUs.

\section{METHODS}

\subsection{Study Area}

Ulu Masen ecosystem is located between 4'’20'3 N and 5''30'0 $\mathrm{N}$ between 95' 20 '0 E and 96'30'0 E. This forest area acts as a vital watershed for approximately 300,000 people. The environmental benefits provided to Ulu Masen's rich biodiversity include habitat for at least 300 species of birds, 87 species of reptiles and amphibians, and the globally important Sumatran tiger and elephant populations [8].

Ulu Masen mountains support a diversity of forest types due to their complex geology, climate types, range of soil types, and altitudinal range. Forest type classifications carried out in the past recorded lowland broadleaf forest, pine forest, submontane broadleaf forest, montane broadleaf forest, and other forests. Most of the rich lowland forests covering the plains along the coast have been converted to agriculture and other uses. In most areas above 500 meters, there are still substantial areas of high-quality forest [8].

\subsection{Management Effectiveness Method}

Management Effectiveness Assessment is conducted using Management Effectiveness Tracking Tools/METT. METT can help to (1) examine the overall effectiveness of Protected Areas, (2) identify factors influencing the effectiveness, and (3) determine common threats and their seriousness. (August 2016 to July 2017, 120 respondents were involved, ranging from FMUs, community, and related stakeholders. Questionnaires sheet is used as material for interviews. The value of area management effectiveness can be divided into three categories [9], namely, i.e., if the score is $<33 \%$, then the management is deemed inadequate (ineffective) if the score range is between 33 - 67\%, the management is counted as inadequate (less effective) and if the score is $>67 \%$ : control of the area is quite good (useful).

\subsection{Field Survey Using Camera Trap}

In 2017 - 2018, a camera trap survey was conducted on the area in two phases. The first phase was undertaken from April to June 2017, and the second phase was completed from August to October 2017. The sampling is 80 cells/stations. Whereas the sampling size is $9 \mathrm{~km}$ square, covering a total area of $720 \mathrm{~km}$ square, and using 160 camera traps of Bushnell Trophy type, Cuddeback, Reconyx. Four groups carried out the surveys consists of 5 persons. The distance between the cameras is $1.9 \mathrm{~km}$. Tiger density analysis is prepared using Software R version 3.1.1 SECR. The camera was recording data for six months, assuming that this is a closed population survey. In addition, it also uses buffering habitat data for $8 \mathrm{~km}$ with an effective sampling area of $104.46 \mathrm{~km}^{2}$. The number of stations is 80 grids with 160 cameras installed. 


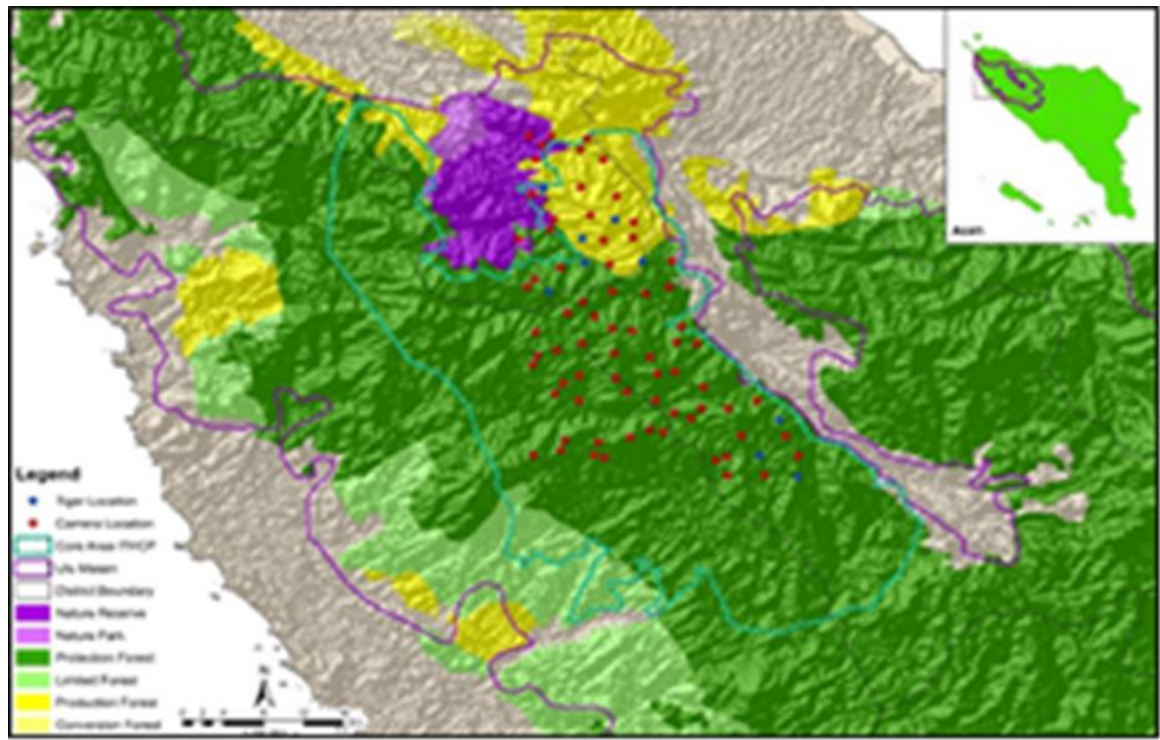

Figure 1 The study area in Ulu Masen Protected Area, Aceh

\section{RESULTS}

Based on the assessment, the result of context is $100 \%$ because this area has the legal status, issued by Forestry Minister Decree and stated as Great Park Area by Decree Number $1 /$ Kpts-11/1998, as protection and production located on the Seulawah Agam Provinsi Daerah Istimewa Aceh.

This area is still under the designing process regarding the blocking of zones. It needs to strengthen the buffer zone to support the area's design as a habitat for Sumatran elephants and Sumatran tigers. The FMU is also recommended to explore the opportunities and efforts to ensure the corridor area across the road, especially at Senapit road, estimated to be the two species' corridor.

The input element only scored about 56\%. The weakness is on law enforcement, the number of employees, and budget. The value of the results in the process element is only about $49 \%$. This area's weakness is the competencies and capacity building, relationship to the indigenous people and traditional communities. This area is also weak because of less support for monitoring and evaluation, including forest monitoring and forest resource inventory. These areas of weakness are crucial; based on the responsibility of FMU as forest management, the weakness must be improved from weak to a strong and reliable status. Based on its function, FMU TAHURA PMI function is as ecotourism, legally supported by Governor Regulation Number 70 the Year 2015 concerning the permit for natural tourism in Aceh. In relationship to the output element, this area is only scored $33 \%$. The weakness of this element is the lack of supporting facilities for the visitor. This situation will result in a decrease in income from ecotourism.
FMU TAHURA PMI, as a great park, is located in the landscape of FMU I. The FMU I score is only about $60 \%$. The high score is at the context element $100 \%$ due to the area's legal status and FMU. In the context of planning, the score is $74 \%$. This FMU strength is in the availability of legal planning documents, including the planning on the use of land and water, regional regulations, regional objectives, and management plans.

On the other hand, the input element only gets about $56 \%$ with weakness in law enforcement, a limited staff, resource inventory, and budget certainty. In the aspect of the process, the score is about 53\%. The weakness area is on protection systems, resource management, lack of staff competencies, cooperation with privateand related government sectors. The priority issue is research, equipment and maintenance, education and awareness, and monitoring and evaluation that are not staffed with regular commercial travel operators. The output element of FMU I have a score of only $17 \%$, but this scoring is made before the management plan document is submitted to MoEF. At this time, the longterm management plan (LTMP) has been submitted to MoEF (Minister of Forestry and Environment), presented, reviewed, and revised. With the LTMP on the waiting list for approval, we assume the score is increased to $70 \%$. This status will be brought to the next step of the assessment.

Using a camera trap survey, we found nine individuals of the Sumatran tiger captured in Ulu Masen's area. A camera trap captured the wild Sumatran tigers. These findings became intense when the surveys also found various threats dominated by traps predicted as tiger traps. Numerous snares were installed up in the forest. During survey periods, there are 3740 trap nights with total independent photos of about 2091 frames. The sampling area covers $675 \mathrm{~km}^{2}$, 
with the distance between the sampling area is $1.9 \mathrm{~km}$. In this survey, eight cameras were lost, and two cameras are broken. All were occurred in the 5-station grid. By this activity, the camera trap only captured three individuals of Sumatran tigers.

\section{DISCUSSION}

According to the status of the current management effectiveness of FMU, the decreasing of the Sumatran tiger population is influenced by the lack of some elements of management effectiveness. The most relevant area related to status is the process area (53\%). In this area, FMUs are not strong enough to complete the protection system, resource management system, lack of staffs' competency. The competency related to forest inventory must be increased since it is needed as the basis of adaptive management. This threat regards the Ulu Masen status area as the prime habitat for Sumatran Tiger, as the Tiger Landscapes conservation. The target area in doubling the Global Tiger Recovery Program number was declared in 2006.

There are some gaps regarding conservation in a policy context, such as the authority gap between national and sub-national authority. There is only FMU as the primary institution related to Ulu Masen's status as a protected area. No institution has been set up that works explicitly as a wildlife species protection unit. Institutionally, Aceh has not been equipped with precise units in dealing with conservation management, wildlife conflict, wildlife trafficking/poaching [10].

Concerning the capacity strengthening for FMUs, in the context of capacity building, no regulation explicitly covers capacity building/human resources development. In Qanun Number 7/2016, the statement about the capacity building is very general and normative. The implication to FMU is then FMU doesn't get sufficient support in the development of staff professionalism. The national government regulation Number 6/2007 doesn't equip with human resources development on FMU [10]. The maintenance of forest ecosystems in Aceh through conservation effort can only be carried out through the work of FMUs, and the quality of FMU work will ultimately depend on the commitment and support of the Aceh provincial government [11].

Based on FMU management effectiveness, this assessment argues as one of the tiger population's threats. It is related to the decreasing number of tiger individuals captured by camera traps and the various threats by human activities such as illegal hunting using snares trap and others. From 2012 to 2016, there are five main findings, i.e., illegal logging, encroachment, illegal hunter and illegal mining, with a total of 1271 cases in the Sumatran tiger survey area.

Related to the International commitment that declared Ulu Masen as Tiger Landscape Conservation and the target area for doubling the number of Sumatran tigers, it becomes an ambitious vision with the actual situation. The institutional strengthening of FMUs and capacity building of its human resources are very much needed.

\section{CONCLUSIONS AND RECOMMENDATION}

In the national context, Sumatran tigers conservation is running now. There is a collaborative stakeholder that has developed the National Strategy for Tiger Conservation. MoEF also has issued the protocol for the Sumatran tiger occupancy survey. Then in the local context, the conservation of the Sumatran tiger is supported by various regulations. A great sound also came from Aceh's People Representative Council in 2018, where one more legal protection to wildlife, including the Sumatran tiger, is now under preparation. The legal protection policy is Aceh Qanun Regulation at the Provincial level. The FMUs for once more, will act as the conservation practitioner in Aceh that will enforce the regulation. In this situation, the FMUs need to be equipped with robust capacity, complete equipment, and a strong financial support position.

\section{REFERENCES}

[1] R. Cochard, Scaling the Costs of Natural Ecosystem Degradation and Biodiversity Losses in Aceh Province, Sumatra, in: G. Shivakoti, U. Pradhan, H. Helmi (Eds.), Redefining Diversity and Dynamics of Natural Resources Management in Asia, Volume 1, Sustainable Natural Resources Management in Dynamic Asia, $1^{\text {st }}$ Edition edition, Chapter 13, Elsevier B.V., 2017, pp. 231-271. DOI: 10.1016/B978-0-12-805454-3.00013-X

[2] S. Stoll-Kleemann, Evaluation of management effectiveness in protected areas: Methodologies and results, Basic and Applied Ecology, 11(5), 2010), pp. $377-382$. https://doi.org/10.1016/j.baae.2010.06.004

[3] N. Dudley, J.D. Parrish, K.H. Redford, S. Stolton, The revised IUCN protected area management categories: The debate and ways forward, Oryx, 44(4), 2010, pp. 485-490. https://doi.org/10.1017/S0030605310000566

[4] R. Kasia, W. Azmi, M. Ismail, J. Dunlop, D. Kiswayadi, Halimatussa'diah, F. Tryshanie, H. Isha, N. Almasri, M. Linkie, Tackling Illegal Logging in Ulu Masen, Aceh: Strategy, Action and Future Direction, Flora \& Fauna International, Banda Aceh, 2011.

[5] World Bank, Global Tiger Recovery Program 2010-2022, Program, June, 70, 2010. 
[6] H.T. Wibisono, M. Linkie, G. Guillera-Arroita, J.A. Smith, Sunarto, W. Pusparini, Asriadi, P. Baroto, N. Brickle, Y. Dinata, E. Gemita, D. Gunaryadi, I.A. Haidir, Herwansyah, I. Karina, D. Kiswayadi, D. Kristiantono, H. Kurniawan, J.J. Lahoz-Monfort, N. Leader-Williams, T. Maddox, D.J. Martyr, Maryati, A. Nugroho, K. Parakkasi, D. Priatna, E. Ramadiyanta, W.S. Ramono, G.V. Reddy, E.J.J. Rood, D.Y. Saputra, A. Sarimudi, A. Salampessy, E. Septayuda, T. Suhartono, A. Sumantri, Susilo, I. Tanjung, Tarmizi, K. Yulianto, M. Yunus, Z. Zulfahmi, Population status of a cryptic top predator: An island-wide assessment of tigers in Sumatran rainforests, PLoS ONE, 6(11), 2011.

DOI: https://doi.org/10.1371/journal.pone.0025931

[7] M.A. Sardjono, M. Inoue, Collaborative Governance of Forest, in: G.P. Shivakoti, S. Sharma, R. Ullah (Eds.), Redefining Diversity and Dynamics of Natural Resources Management in Asia, Elsevier Inc., 2017, pp. 175-187. DOI: https://doi.org/10.1016/B978-0-12-8054543.00011-6

[8] The Provincial Government of Nanggroe Aceh Darussalam (Aceh), Reducing Carbon Emissions from Deforestation in the Ulu Masen Ecosystem, Aceh, Indonesia: A Triple-Benefit Project Design Note for CCBA Audit, Fauna \& Flora International and \& Carbon Conservation Pty. Ltd, 2008, pp. 172. Retrieved from papers3://publication/uuid/9AAFC784-7A87462C-884A-B6BF3410FAC6

[9] F. Leverington, M. Hockings, K. Costa, Ghana National Development Planning Reports, Mci, 2008.

[10] S. Iriyani, A.H. Hamid, A. Setyarso, Provincial Autonomy and Forest Management Unit (FMU) Legislation in Aceh Province, Indonesia, A Review of Regulatory Asynchronies, 2018, pp. 1-15.

[11] S. Iriyani, A.H. Hamid, A. Setyarso, H. Basri, The legal basis for Forest Management Units as Conservation practitioners in Aceh Province, Indonesia, 2018. 